\title{
Early Development of Muhammadiyah Education in Sorong, West Papua
}

\author{
$1^{\text {st }}$ Anang Triyoso ${ }^{1}, 2^{\text {nd }}$ Ari Wibowo ${ }^{2}, 3^{\text {rd }}$ Muhammad Kartono $^{3}$ \\ \{atriyoso@yahoo.com ${ }^{1}$, arisuryasorong@yahoo.co.id ${ }^{2}$, kartonowpb@gmail.com²\} \\ Universitas Pendidikan Muhammadiyah Sorong, West Papua, Indonesia ${ }^{12}$
}

\begin{abstract}
The Most of early developments of Muhammadiyah education in Indonesia only narrated perspectives that were always represented by several regions. In fact, Muhammadiyah education has developed in various territory and has different characteristics. Many facts are ignored and not recorded in a historical social context which certainly has a national dimension. Likewise, the Muhammadiyah movement in Sorong, West Papua has not been much revealed. This research uses historical methods, including heuristics, source criticism, interpretation, and historiography. Data collection methods used are interviews, observation, archives and literature. Data is sorted, processed and the results are presented in the form of historiography. The results of the study showed that the early development of Muhammadiyah education was passed through a persistent effort (through consistency of recitation) from the characters. These developments include charity education efforts. This is evident from the various existing charity education efforts such as schools from kindergarten to college. The conclusion is that Muhammadiyah Sorong can develop itself and advance its society, through education making Sorong as a center of excellence for the education of Muhammadiyah throughout Papua.
\end{abstract}

Keywords: Development, Education, Muhammadiyah, Sorong.

\section{Introduction}

There are two reasons for writing the initial development of Muhammadiyah education in Sorong, Papua. First, the scope writing of the early development of Muhammadiyah education is still macro-historical. The Most of writings on the development of Muhammadiyah education in Indonesia are developing only narrating perspectives which are always represented by several regions including Yogyakarta. In fact, Muhammadiyah education has developed in various territory and has different characteristics both in terms of entry, time, background, acceptance, and social cultural conditions. Second, the writing of the early development of Muhammadiyah education was very limited after the first generation of Muhammadiyah was born. As a result, many dynamics and facts are ignored and not recorded in the current historical social context. Likewise, the Muhammadiyah education movement in Sorong Papua in the Muhammadiyah historiography in Indonesia, has not been much revealed. Perhaps because Sorong Papua is considered as the peripheral region of the Muhammadiyah in the archipelago and has not been touched by the influence of its movement.

Writing about the perspective of local development is very important to do. Local perspectives can help "eliminate" the generalization of the development of Muhammadiyah education that develops in the local area. A comprehensive historicity approach can provide 
clear answers to these phenomena and at the same time can provide clear directions for policy makers to reconstruct good policies. Without the use of a local historical perspective, reading of the social cultural characteristics of the community will experience absurdity.

The Sorong region, which is located in the Papuan Bird's Head, is considered a "far" area of the flow of the Muhammadiyah period. The entry of Islam (through the Muhammadiyah movement) in Sorong was not much discussed. For example Weinata Sairin (Sairin, 1995) in his book "Muhammadiyah Reform Movement" and Toni Victor M. Wanggai (Wanggai, 2009) in his book "Historical Reconstruction of Muslims in Papua "There is very little mention of the development of Muhammadiyah education in Sorong.

The effort to write the initial development of Muhammadiyah Education in Sorong is not an easy matter, this is inseparable from the many sources that must be explored as writing material. We race against time because more and more key Muhammadiyah figures in Sorong have died before documented their thoughts. Prof. Dr. Din Syamsuddin during a visit to Sorong revealed that "Muhammadiyah's enlightenment mission is very good in Sorong City and in Sorong Regency". Sorong is used as a research base, considering its history is a parent district which has been divided into several districts which include the cities of Sorong, Raja Ampat Regency, South Sorong Regency, Maybrat Regency and Tambrauw Regency.

Based on the above, this research aims to formulate the early development of the establishment of Muhammadiyah education in Sorong. Similarly, explaining the stages of development of Muhammadiyah education in Sorong until the reform era.

\section{Research Methodology}

This research uses historical methods, can be interpreted as a process of testing and analyzing historical testimonies in order to find authentic and reliable data, and efforts to synthesize such data can be a reliable historical story (Gottchalk, 1986).

The steps in the historical research are:

1) Heuristics is the first step to collect resources related to the object of research. Data collection is obtained from primary and secondary sources. The primary source used is the result of interviews with the perpetrators of the history of the early development of Muhammadiyah Education in Sorong. Secondary sources are obtained from books, magazines, scientific journals, and related document archives;

2) Source criticism (verification), namely the process carried out by researchers to find the truth value of the data so that it can be objective research. This is done to obtain the authenticity of the sources that have been collected. Thus all data obtained must be investigated to obtain valid facts;

3) Interpretation, which is the stage where the researcher tries to connect the data obtained in the field with the facts that exist. So that the data is expected to be objective data without any element of subjectivity that affects the results of writing; and

4) Historiography, is a way of writing, presentation, or reporting the results of historical research conducted. 


\section{Result and Discussion}

\subsection{Result \\ 3.1.1 Muhammadiyah Movement Begins to Integrate with the Republic of Indonesia and the New Order Era, 1963-1998}

After West Irian officially joined the NKRI region on May 1, 1963, the influence of Muhammadiyah in Fakfak, Kotabaru, Sorong Besar, Sorong Raja Empat, and Manokwari was spurred by H. Ibrahim Bauw (Radja Rumbati) and regional officials and employees country that is a member of Muhammadiyah. Narrated by H. Nurdin Nais (entering West Irian in 1965, originally from Makassar), as an Islamic leader H. Ibrahim Bauw was very well known among natives and migrants. As a native of Papua, H. Ibrahim Bauw was also a successful log businessman and collaborated with Japanese people.

Since joining the NKRI region, to accelerate the integration process, the government has sent educated and trained personnel and spontaneous migrants. Both as government officials, teachers, traders including pertamina employees, Sorong. From here onwards Muhammadiyah began to develop again, because most Muslims who entered Sorong were from Muhammadiyah circles.

In 1963, the Muhammadiyah organization was officially established in 1963 in Sorong. With branch status, Muhammadiyah is chaired by Usman Saad. According to the document of the establishment of Muhammadiyah Sorong owned by the PDM in Sorong City as stated by cleric Samsul Arifin, it originated from the story of one of the early generations of Sorong Muhammadiyah namely La Dena, that during the transition from UNTEA, the Indonesian Government in Jakarta sent representatives from the Development Department and Department Attorney. At that time the Prosecutor's Office was headed by Hadrat Hamid who was from Padang. Upon his arrival at Sorong Hadrat Hamid, a Muslim, he met with several Islamic leaders to discuss the lack of understanding of Islam and the large number of children who did not attend school.

As a member of Muhammadiyah, Hadrat Hamid brought the mandate of PP Muhammadiyah to form a Muhammadiyah organization in Sorong. Meet later with La Dena and discuss the establishment of Muhammadiyah in Sorong. Then as material to get to know Muhammadiyah, La Dena was given the constitution and household budget of the Muhammadiyah to be studied. Then La Dena met Usman Saad while handing over the Muhammadiyah constitution and by-laws to study. Usman Saad is a well-known Muslim leader in Sorong, who comes from the Southeast Maluku region. He worked at the Military District Command Sorong as a civil servant, often going back and forth to Jakarta, especially in matters relating to security. In addition to civil servants, he is also known as a preacher.

At the beginning of wanting to establish a new organization, the religious views of some Muslims who considered Muhammadiyah were young religions. In order not to be considered a young religion by Muslims in Sorong, then Usman Saad and La Dena met with Islamic leaders at that time to explain the purpose and purpose of the establishment of the Muhammadiyah organization. Among the figures encountered were Abdul Rasyid Arfan (as a native Papuan son and Papuan Muslim leader who was a member of the MPRS from the representatives of Sorong West Irian), Muhammad Al-Hamid, Muhammad Arsyad, Abu Bakar, Harmis Rumages, Musa Wasaraka, Salim Sabandafa, and youth and so on. Usman Saad explained to the figures visited that this organization was not a young religion, but the aim and purpose of Muhammadiyah was to establish educational institutions for children to learn religion, know Islam, and be close to 
God. Because at that time Usman Saad was considered a mubaliqh and respected, finally he was able to accept and approve the establishment of the Muhammadiyah organization in Sorong.

This good news was then conveyed to Hadrat Hamid and happily went to KPS (head of the Sorong government) namely Hambali Tagada, BA to plan the inauguration of Muhammadiyah Sorong Branch. Thanks to the contribution of the Head of the Sorong Government at that time, the official launch of the Muhammadiyah Sorong Branch was completed and completed with the following arrangement: Usman Saad (Chair), Abdul Rasyid Arfan (Deputy Chair), La Dena (Secretary), Muhammad Al-Hamid (Chairperson of Youth), Muhammad Arsyad (Chair of Development), Salim Ibrahim (Chair of Spirituality), and Baco (Information Coordinator).

The first plan carried out in accordance with the purpose of establishing Muhammadiyah Sorong when meeting Islamic leaders before hand was to build a school room for children to learn religion and general knowledge. The first school was built in South Remu at the home of a Chinese person named Angco Beng, namely the Madrasah Diniyah school (SD Negeri 2 now), the teachers were Muhammadiyah administrators and assisted by teachers brought in from the Muhammadiyah Central Leadership.

The establishment of Muhammadiyah schools continued in 1970 to establish ABA 1 Kindergarten, namely on Jalan Jenderal Yos Sudarso Kampung Baru. The building of the ABA 1 Kindergarten occupied by the original story was the result of the Dutch colonial spoils to the Republic of Indonesia. The buildings by KPS (interim head of government) Sorong were divided among several parties, including those who got them were Cenderawasih University, Sorong Vocational School, and Muhammadiyah. Division of spoils of war which regulated Hambali Tagada as KPS (head of the interim government) Sorong. To complete the school infrastructure, Muhammadiyah administrators took the initiative to raise funds to procure it through the Head of the Dolog when the results of sweeping rice (scattered rice) were collected and sold to buy benches, tables, and so on. But over time, ABA 1 Kindergarten switched ownership status.

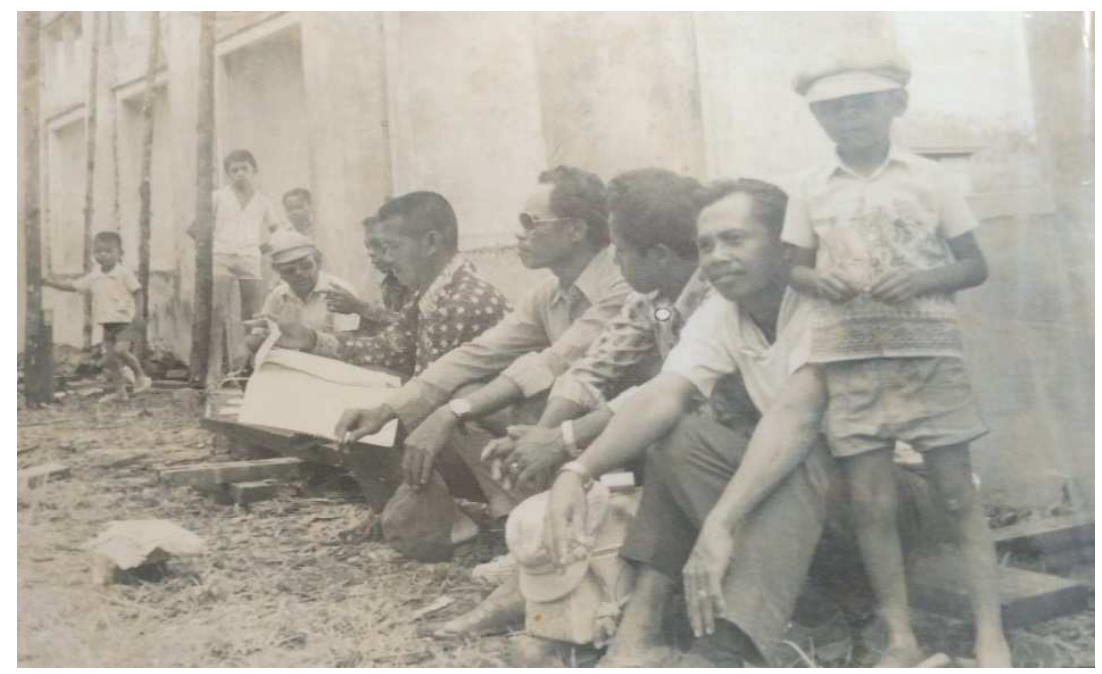

Figure 1. Seated from left right: La Dena, Nurdin Nais, Usman Saad, and Muhammad Aman 
The primary school education facility that was first established by Muhammadiyah was the Muhammadiyah Ibtidaiyah Madrasah. Because the public's enthusiasm is still lacking in incorporating their children into religious schools, Muhammadiyah cautioned by changing its name to SD Al Jihad with a curriculum that still refers to the rules applied by the Dikdasmen PP Assembly.

The Regional Leader of Muhammadiyah Sorong then began to think about and make plans to establish a Muhammadiyah business charity in the field of education. In 1976 SD Muhammadiyah 1 Sorong was established. The school location is close to the Remu stream, Pisang Village in Sorong and is not very strategic. The construction of the elementary school began with the capital proceeds from the sale of wakaf (donated) land from the Servant of Allah which granted the plot in the Senior High School complex. The mission was sold for Rp. $1,500,000.00$ for the approval of the recipient. The money is not enough to build six class for elementary school, so with the courage of the PP\&K Council for the assistance of Drs. Maradi, Head of BRI Sorong Branch, can get a loan of Rp. 10,000,000.00 with guaranteed elementary school land that has not been completed with the management of the documents.

In 1977, the transmigration program entered Sorong Regency. Some customary land was diverted to the transmigration program which began with the release of customary land in Klasaman covering an area of 10,000 hectares, which in fact only used 2,000 hectares for settlement and agriculture, the rest were not suitable for transmigration programs. The presence of transmigrants from Java Island gave a new color to the development of Islam because most of them were Muslim.

Then in 1978 the Muhammadiyah Regional Sorong Musda II was held in the period 19781981. The elected executive board members of the Sorong Regional Muhammadiyah from 1978 to 1981 were Rahman Yeubun (Chair) and Nurdin Nais (Deputy Treasurer).

In the leadership period of Rahman Yeubun, Muhammadiyah Junior High School was established. The educational institution founded by Muhammadiyah Organization in 1978 was the education of the first Muhammadiyah cadres who took part in enlivening the arena of community organizations in Sorong Regency. With the establishment of Muhammadiyah Junior High School, it marked the formation of an organization which at the same time became the Muhammadiyah Autonomous Organization at the student level, the Muhammadiyah Student Association. Muhammadiyah Junior High School began teaching and learning activities on Jalan Merpati No.17 Al Amin Sorong mosque complex.

After having educational institutions from kindergarten to junior high school level, it is incomplete if the educational institution does not continue to a higher level. Finally in 1984 Muhammadiyah Senior High School was established in Sorong and carried out teaching and learning activities in the afternoon until late afternoon at the Sorong Muhammadiyah Junior High School building.

The following is an illustration of the state of Muhammadiyah school as of December 31, 1984 as in the following table.

Table 1. State of Muhammadiyah Schooling on 31 December 1984

\begin{tabular}{clccccc}
\hline \multirow{2}{*}{ Number } & School & Quantity & $\begin{array}{c}\text { Civil } \\
\text { servant }\end{array}$ & $\begin{array}{c}\text { Permanent } \\
\text { Foundation }\end{array}$ & Honorarium \\
\hline 1. & TK & 9 & 1 & 19 & - & 512 \\
2. & SD & 3 & 14 & 6 & - & 544 \\
3. & M. Diniah & 3 & - & 5 & - & 98 \\
4. & SMP & 1 & 6 & 4 & 5 & 272
\end{tabular}




\begin{tabular}{ccccccc}
\hline \multirow{2}{*}{ Number } & School & Quantity & $\begin{array}{c}\text { Civil } \\
\text { servant }\end{array}$ & $\begin{array}{c}\text { Permanent } \\
\text { Foundation }\end{array}$ & Honorarium & \\
\hline 5. & SMA & 1 & - & 5 & 9 & 174 \\
6. & MTs. & 1 & - & 1 & 4 & 24 \\
7. & STIA & 1 & - & 4 & 28 & 252 \\
\hline & Total & 19 & 21 & 44 & 46 & 1.876 \\
\hline
\end{tabular}

Muhammadiyah Sorong studied the situation and conditions and the requirements regarding the establishment of Muhammadiyah colleges / universities in Sorong. Establishing a college was not easy because many of the requirements that must be met include, among other things, a foundation that supports / establishes which has the principles of Pancasila and the 1945 Constitution. When it was established of STIA (Al Amin Administrative Sciences high school) was discussed at $\mathrm{H}$. Pulukadang's residence, who were present at the Muhammadiyah figures, including being attended by the Head of Bulog Sorong because the conditions for establishing must have a foundation, the Al Amin Foundation was formed.

Through AM Muharram who is trusted to take care of Kopertis IX region in Ujung Pandang, it was decided that the college to be established was the Al-Amin College of Administrative Sciences under the Al-Amin foundation formed by Muhammadiyah. All requirements requested have been fulfilled, STIA has registered status with SKEP number: No. 0519 / O / 1984, dated October 30, 1984. This decision was submitted directly by the Director General of Private Universities (GUTISWA) Prof. Dr. Ir. Sutrisno Hadikumoro SH along with Kopertis Region IX, on November 27, 1984 at the Sorong Regional Government building. STIA (now transformed into Muhammadiyah Sorong University) is the only first campus in Sorong, formerly at the Al-Amin mosque complex, next to the Sorong Sub-District Office.

\subsubsection{Muhammadiyah Movement Era of Reformation and Regional Expansion, 1999- 2005}

After the division of Sorong into two regional administrations, Muhammadiyah leaders responded quickly to also expand Muhammadiyah to adjust to regional expansion. At Musda VII on 24-25 February 2001, the Muhammadiyah Regional Leadership (PDM) of Sorong Regency stood alone, separated from the Sorong City PDM which had existed since the 1960s. Musda chooses Drs. H. AM. Mustamin as chairman of PDM in Sorong City and Drs. Rustamadji as chairman of the PDM in Sorong Regency.

In 2000, Muhammadiyah in Sorong Regency entered a new era. The Da'wah seeds planted by the da'I since the 1960s, have found momentum to grow, begin to produce and spread everywhere. When formed, the Sorong Regency PDM only had a few kindergarten. It building was once a transmigration house that was abandoned by its owner and was on the side of the road. According to Drs. Rustamadji, the condition of the house is very simple. Because simply, the house does not need to be bought by Muhammadiyah. The owner just gave it to Muhammadiyah. During the period 2000-2004, the PDM established another business charity, in the form of: Elementary, Junior High School, Senior High School, Vocational School and even college.

In addition, the PDM Sorong has also gained high trust from the community. This is indicated by the presence of 30 people who have inherited their land for Muhammadiyah. According to Drs. Rustamadji, these lands are acquired in various ways. Some are based on endowments, collective endowments and some are obtained from the purchase. As a note that 
the development of land prices in this location is very fast. In 1989, one hectare of land that became the location of the transmigration was only worth one million rupiah. In 2010 , the price was 800 million to 1 billion rupiah per hectare.

Paying attention to the real conditions of the people in Sorong Regency in order to mobilize and support charity, please help in virtue and piety in the social field, then formally establish the Muhammadiyah Orphanage with Decree No. 091 / SK-PD / IV.A / 2.a / 2000. Furthermore, the Muhammadiyah Orphanage as a social organization dated March 13, 2001 has been officially registered with the Social Service Office of Sorong Regency, Irian Jaya Province with an Organization Registration Number No. 466.3 / 44 / Orsos / Srg / 2001 with the field of assistance for orphans, poor and neglected children.

The monumental pioneering business of PDM in Sorong Regency is STKIP Muhammadiyah Sorong. The initiative of the establishment of higher education emerged when the Muhammadiyah Regional Leader of Sorong Regency in the period 2000-2005 was under the leadership of Drs. Rustamadji held the Regional Working Meeting (RAKERDA) of the Primary and Secondary Education Council at Aliyah Madrasah of Muhammadiyah Aimas on November 13, 2001. It produced a work program, one of which was to propose the establishment of STKIP Muhammadiyah Sorong in 2003.

In 2003, the Muhammadiyah PP Decree number 78 / KEP / I.0 / D / 2003 was issued on September 20, 2003, concerning the appointment of the Chairperson of the first STKIP Muhammadiyah Sorong was Drs. Rustamadji, had previously resigned as Chair of the Muhammadiyah Regional Leader of Sorong Regency. Then in 2004, during a visit by the Muhammadiyah PP team, Prof. H. Zamroni, Ph.D. et al to Sorong Regency brought the good news that the Indonesian Ministry of National Education Prof. Drs. HA. Malik Fadjar, M.Sc. has approved the establishment of STKIP Muhammadiyah Sorong and can immediately accept new students. Finally, on August 19, 2004 a Republic of Indonesia Decree No. 127 / D / O / 2004 was issued concerning the Granting of Permit for the Implementation of Study Programs and STKIP Muhammadiyah Sorong.

Initially, this high school started educational activities at the Muhammadiyah college complex that was used in conjunction with educational units from elementary, junior high, Tsanawiyah Madrasah and Aliyah Madrasah. Course are held in the afternoon until evening at 8:30 p.m. In this complex there is a land owned by Muhammadiyah Organization covering an area of 3.25 hectares. However, holding it all out is still too narrow to build a large campus in the future.

Then, in 2007 it was searched and bought for an area of 3 hectares which was 1.5 kilometers from the location of the Muhammadiyah college complex. This vast land was originally a land of land which was not at all glimpsed by people. This land is in the transmigration area. Many people doubt the decision to buy land which is actually very perspective, even from Muhammadiyah's own citizens. But Drs. Rustamadji, et al. Remain consistent with their position to buy the land.

The process of buying land is unique. This owner is a Muslim who has been on the Hajj. First of all, he offered Rp. 250,000,000, but exactly the next day, Pak Hajj raised the price to Rp. 350,000,000. Strangely, Drs. Rustamadji and his friends responded to the ordinary, not with anger and annoyance. "At that time, if we were angry and emotional, maybe the campus of STKIP Muhammadiyah Sorong wouldn't stand there". Now the price of land around the Muhammadiyah campus has soared. Within eight years, the price of the land reached 4 billion rupiah / hectare.

After STKIP Muhammadiyah Sorong bought 3 hectares of land, what was the first time built? Mosque. Syahdan, the funder of the construction of the campus mosque (Amalbhakti 
Muslim Pancasila Foundation) once asked wonder: where is the campus? People also ask in a minor tone: who will pray here? Because around the campus there are no residents and far from settlements. These questions certainly follow the way of thinking commonly used by people in Jakarta, Yogyakarta, and Java. According to Mr. Rustam, this way of thinking cannot be applied in Papua and must be changed. The answer given is that the construction of a mosque in a land that is far from the settlement is based on the saying "there is sugar, there are ants". Mosques are sugars that will be visited by Muslims from all parts of the region. The STKIP Muhammadiyah Sorong Mosque invites Muslims to worship, to study on campus and to make settlements and public facilities around it.

\subsection{Discussion}

The presence of Muhammadiyah in the Sorong region since 1963 marked the emergence of other Islamic organizations with preaching activities and charitable endeavors. In line with the paper stating that the Nadhatul Ulama and Muhammadiyah have been present in Sorong since the 1960s (Saprillah, 2011), but based on the historical tracing conducted organically the first time that has been established is the Muhammadiyah Branch of Sorong in 1963. Next, based on research results the history of Muslims in the land of Papua since 1963 there are many Islamic diversity organizations in West Irian, starting from Muhammadiyah, Nadhatul Ulama, Darul Da'wah wa al-Irshad and others (Wanggai, 2009).

Usman Saad's figure as chairman and at the same time which was held among Muhammadiyah members was very central. Activities include meetings and recitation from house to house. As a elder, every Usman Saad recitation which guides the reciters and becomes a role model for the community. Recitation became the spirit of the Muhammadiyah movement at that time. Islamic movements that spread to various regions in Indonesia, in the beginning were recitation (usroh) led by a religious teacher who faithfully fostered his congregation routinely accompanied by high member commitment (Jinan, 2015). From this study Muhammadiyah in Sorong was established, and this was also experienced by other regions in Indonesia (Afnan, M. \& Kasdi, A, 2013).

In the next development, because the da'wah movement was only based on figures, this led to the development of Muhammadiyah education in Sorong at that time not so fast. This condition is caused by the very limited source of propulsion, therefore the spread of the influence of Muhammadiyah is mainly played by a chairman (Afnan, M. \& Kasdi, A, 2013).

Like religious organizations, then at the beginning of the pioneering Muhammadiyah education facilities were needed in the form of schools / madrasas. The masification of the Muhammadiyah movement took place in Sorong Regency since 2000. Such high enthusiasm was reflected in the statement of Muhammadiyah leaders in Sorong Regency. Drs. Rustamadji, M.Sc. for example, the former PDM Chair who is now the Chair of STKIP Muhammadiyah Sorong, said: "The PDM of Sorong Regency was established in 2000. The area is a transmigration area with very limited quality of human resources. However, we have a high fighting spirit. Begin to do a great work. Later in the process we will get miracles, things that will not be obtained by those who do not start. "

For Rustamadji, Muhammadiyah's success is not determined by the place. It doesn't have to be at the place of birth Muhammadiyah is just advancing! The key is the persistence of Muhammadiyah citizens. In the end, Rustamadji hoped that Muhammadiyah cadres in Java should not hesitate to come to Papua. "Come here. This is where the forging, fertile fields and places to fight. In Jogja there will not be militant cadres appearing because they are already calm 
and peaceful. Come here and don't complain, then it will be great here. The land of Allah is not only in Jogja, (Tago, 2011).

The charity activities of the Muhammadiyah education effort in Sorong have a great influence on the surrounding community, in terms of their charity efforts, Muhammadiyah has many charitable businesses in the field of education. If traced, and this is what astonishes the world, not only because Muhammadiyah has large material capital (such as state-owned or multinational corporations), but more because social capital comes from the energy and stretch of Muhammadiyah worshipers at the grassroots level (Sari, 2012).

\section{Conclusion}

The founding factors of Muhammadiyah in Sorong are among others the first is that there are still many Muslim children who have not been able to recite or read the Al'Qur'an, are blind about Islam, or go to public school. Secondly, there are many Muslim migrants from Java, Bugis, Makassar and Buton, whether as traders, laborers (laborers), or teachers who have known the Muhammadiyah movement in their home areas first. Third, the presence of civil servants in Indonesian government institutions in Sorong contributed to the mandate to establish Muhammadiyah in Sorong.

The initial response of the Islamic community in Sorong when the introduction of Muhammadiyah was diverse, there were those who considered Muhammadiyah to be a young religion. Observing these conditions is certainly not an easy thing for Muhammadiyah pioneers to broadcast their da'wah. Various efforts were made by the pioneers of Muhammadiyah in addressing this condition, including friendship with Muslim leaders at that time, especially from among indigenous Papuan Muslims. The tit for tat and accepting Muhammadiyah's presence even many indigenous Papuan leaders were included in the initial stewardship of the Muhammadiyah Sorong Branch.

Muhammadiyah Sorong in managing its business charity is based on seeking God's blessing solely for the benefit of society, its Islamic syari'ah style. This can be proven by the establishment of schools, madrasas, orphanages and various other business charities that are spread in Sorong. The Islamic da'wah movement through this charitable endeavor has been directly felt and benefited by the Sorong community. All charitable endeavors run with a foundation for charity and realizing the true Islamic community. The key to the development of Muhammadiyah education in Sorong is none other than sincerity, patience, and perseverance to be the main capital of the managers of Muhammadiyah and its charitable efforts in the process of renewing (tajdid) to the Sorong community.

The existence of Muhammadiyah Organization which was shown in its effort to develop itself and advance the community in Sorong, through education certainly could make

Sorong a center of excellence for the da'wah movement of Muhammadiyah throughout Papua.

\section{References}

[1] Afnan, M. \& Kasdi, A. Perkembangan Muhammadiyah di Mojokerto Tahun 19902012. AVATARA, e-Journal Pendidikan Sejarah, 493-502. . (2013).

[2] Gottchalk, L. Mengerti Sejarah (terjemahan Nugroho Notosusanto). Jakarta: UI Press. (1986). 
[3] Jinan, M. Menguatkan IKatan Bermuhammadiyah (Sebuah Refleksi Penelitian Gerakan Islam). Tajdida , 103-113. (2015).

[4] Sairin, W. Gerakan Pembaharuan Muhammadiyah. Jakarta: Pustaka Sinar Harapan. (1995).

[5] Saprillah. Migrasi Kaum Muslim ke Sorong Papua Barat. Al-Qalam , 251-261. (2011).

[6] Sari, Z.. Peran PTM dalam Pemberdayaan Cabang dan Ranting Muhammadiyah. Retrieved $11 \quad 18, \quad 2016, \quad$ from lpcr.muhammadiyah.or.id: http://lpcr.muhammadiyah.or.id/artikel-298-detail-peran-ptm-dalam-pemberdayaancabang-dan-ranting-muhammadiyah.html (2012, 10 23)

[7] Tago, M. Z. Mubaligh Perintis dan Geliat Dakwah di Sorong Papua. In M. PPM, Berkala Tuntunan Islam (pp. 56-60). Yogyakarta: Majelis Tabligh PP Muhammadiyah (2011).

[8] Wanggai, T. V.: Rekonstruksi Sejarah Umat Islam Di Tanah Papua. Penerbit Balitbang Depag R, Jakarta (2009) 


\section{References}

[1] Somov, A.: Wildfire safety with wireless sensor networks. EAI Endorsed Transactions on Ambient Systems. pp. 1-11 (2011)

[2] Motaz, A.: Start programming using Object Pascal. Vol. 2, pp. 10-11. Legally Free Computer Books, US (2013) 